\title{
Guinea pigs experimentally infected with vaccinia virus replicate and shed, but do not transmit the virus
}

\author{
Cobaias infectadas experimentalmente com vírus vaccínia replicam e excretam, porém \\ não transmitem o vírus
}

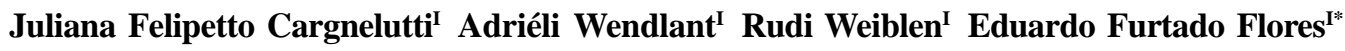

\begin{abstract}
The origin of vaccinia viruses (VACV) associated with vesicular disease in cattle and humans in Southeast Brazil remains uncertain, yet the role of wild species in virus transmission has been suggested. This study investigated the susceptibility and transmission potential by guinea pigs (Cavia porcellus) - phylogenetically close to an abundant Brazilian rodent (Cavia aperea) - to two VACV strains (P1V and P2V) isolated from an outbreak of cutaneous disease in horses in Southern Brazil. Eight guinea pigs inoculated intranasally with P1V and P2V $\left(10^{6}\right.$ TCID $\left._{50} . \mathrm{ml}^{-1}\right)$ did not develop clinical signs, but six animals shed virus in nasal secretions (day 1 to 9 postinoculation - pi), developed viremia (between days 1 and 10 pi) and seroconverted to VACV. In spite of virus replication and shedding, the virus was not transmitted to sentinel animals by direct or indirect contact (aerosols) or through food and water contaminated with virus. These results demonstrate that, in spite of replicating and shedding the virus, guinea pigs do not transmit the virus upon experimental inoculation. This finding makes unlikely a possible participation of related species in VACV maintenance and transmission in nature.
\end{abstract}

Key words: Cavia porcellus, Cavia aperea, Orthopoxvirus, transmission, epidemiology.

\section{RESUMO}

A origem dos vírus vaccínia (VACV), envolvidos em surtos de doença vesicular em bovinos e humanos no Sudeste do Brasil, permanece desconhecida, e a participação de espécies silvestres na manutenção e transmissão do vírus tem sido sugerida. O objetivo deste trabalho foi investigar a susceptibilidade e o potencial de transmissão por cobaias (Cavia porcellus) - filogeneticamente relacionada a uma espécie de roedor, conhecido por preá (Cavia aperea), bastante abundante no país - a duas cepas de VACV (P1V e P2V) isoladas de um surto de doença cutânea em equinos no Rio Grande do Sul. Oito cobaias inoculadas pela via intranasal com uma mistura das amostras P1V e P2V $\left(10^{6} \mathrm{DICC}_{50} \cdot \mathrm{ml}^{-1}\right)$ não apresentaram sinais clínicos, porém seis animais excretaram o vírus nas secreções nasais (1 a 9 dias pós-inoculação - pi), desenvolveram viremia (1 a 10 dias pi) e soroconverteram ao VACV. Apesar da replicação e excreção viral, o vírus não foi transmitido a sentinelas por contato direto, indireto (aerossóis) ou por água e alimentos contaminados com fezes deliberadamente contaminadas com o vírus. Esses resultados demonstram que, apesar de replicar e excretar o vírus, as cobaias não transmitem o VACV nas condições estudadas. Esses achados tornam pouco provável a participação de espécies relacionadas na manutenção e transmissão do VACV na natureza.

Palavras-chave: Cavia porcellus, Cavia aperea, Orthopoxvirus, reservatórios, epidemiologia.

Vaccinia virus (VACV) is the prototype member of the family Poxviridae, genus Orthopoxvirus, whose infection results in vesiculopustular and scab lesions, mainly in cattle and man (BULLER \& PALUMBO, 1991). In Brazil, several outbreaks of VACV infection have been described since the 90's, especially in the Southeast region. These cases were characterized by vesicular and pustular lesions in the udder and teats of milking cows; in the lips, tongue and muzzle of suckling calves and, occasionally, on the hands and fingers of milkers (DAMASO et al., 2000; SILVA-FERNANDES et al.,

ISetor de Virologia, Departamento de Medicina Veterinária Preventiva, Centro de Ciências Rurais (CCR), Universidade Federal de Santa Maria (UFSM). Av. Roraima, 1000, 97105-900, Santa Maria, RS, Brazil. E-mail: eduardofurtadoflores@gmail.com. *Autor para correspondência. 
2009). The origin of these viruses has been a matter of debate, but is still uncertain. During decades, VACV was used as the vaccine strain in the world programme of eradication of smallpox, due to its low virulence and antigenic similarity with the agent of smallpox, variola virus (VarV) (BAXBY, 1977). Thus, it has been suggested that the virus causing these outbreaks was originated from a vaccine escape virus. Later evidences, however, argue against this hypothesis and indicate an autochthonous origin of these VACV strains, possibly maintained in wild species and occasionally transmitted to cattle and man (KROON et al., 2011). Hence, potential reservoirs for VACV in nature have been investigated by serology and virus isolation attempts from wild rodents (da FONSECA et al., 2002; ABRAHÃO et al., 2009).

An outbreak of cutaneous disease in horses was described in Southern Brazil in 2008, in which a mixed VACV infection was demonstrated. Two VACV strains (P1V and P2V), belonging from different genogroups, were isolated from the same sick animal (BRUM et al., 2010, CAMPOS et al., 2011). The origin of this outbreak is still under investigation yet some hypotheses have been considered and, progressively discarded. First, the introduction of the virus into the herd through an infected horse is very unlikely. VACV infection in horses is very rare and this is the first report in Brazil. In addition, no animal had been introduced into the herd in the period preceding the outbreak. Second, the introduction through an infected bovine is also unlikely since the farm raises exclusively horses and there is no report of such disease in cattle in neighboring farms (BRUM et al., 2010). Third, the farm where the outbreak occurred is far distant from the cattle and human outbreaks in Southeast Brazil. As a part of the epidemiological investigation, a serological survey in cattle and horses of the region of the outbreak was conducted, with negative results. Then, a serological survey in some wild mammals of the region was performed, also yielding negative serology. Concomitantly, we investigated the susceptibility of some species to VACV strains P1V and P2V.

Rabbits were shown to be highly susceptible to these strains and developed severe systemic disease upon nasal or cutaneous inoculation (CARGNELUTTI et al., 2011, 2010). Mice are also highly susceptible to VACV P1V e P2V (CAMPOS et al., 2012). Based on these studies, rabbits were proposed as a model for VACV pathogenesis (CARGNELUTTI et al., 2011, 2012) and mice have been used for preliminary phenotypic screening of VACV isolates (FERREIRA et al., 2008; CAMPOS et al., 2011).
The present experiment focused on an epidemiological aspect of VACV infection, investigating the susceptibility and transmission potential of P1V e P2V by guinea pigs (Cavia porcellus). Guinea pigs are phylogenetically related to a rodent species (Cavia aperea or “preás”), very abundant in many Brazilian rural areas, including the region of the outbreak. In Rio Grande do Sul state, these rodents are particularly abundant, live in brushes nearby pastures and, thus, share grass pastures with livestock (SANTOS et al., 2008), Thus, our hypothesis was that a rodent species related to guinea pigs (in his case, Cavia aperea) might serve as a reservoir for VACV in nature. As obtaining wild "preás" for the experiment would be difficult, we decided first to investigate the susceptibility and transmission potential of a related species, guinea pigs, to P1V and P2V.

The susceptibility of guinea pigs to VACV was investigated by intranasal (IN) inoculation of eight animals (400 to 500g, adults, both genders) with a mixed inoculum (P1V and P2V, virus titer of $10^{6} \mathrm{TCID}_{50} /$ animal), after anesthesia with ketamine $\left(50 \mathrm{mg} \mathrm{kg}^{-1}\right)$ and xilazine $\left(5 \mathrm{mg} \mathrm{kg}^{-1}\right)$. Animals were monitored daily for 30 days regarding clinical and virological aspects. Nasal swabs were submitted to for virus isolation in Vero cell monolayers, and monitored for cytopathic effect (CPE) during three passages of five days each. Pools of peripheral blood and faeces were submitted to PCR for viral DNA PCR reaction for $v g f$ gene was performed according to ABRAHÃO et al. (2010). Serology was performed in serum samples collected at days 0 and 30 post-inoculation (pi), and submitted to a standard virusneutralization (VN) assay in 96-well plates, testing twofold dilutions of sera against a fixed dose of virus (100 - 200 TCID50/well). Vero cells were used as indicators of virus replication. $\mathrm{VN}$ readings were performed after five days of incubation. The VN titers were considered as the reciprocal of highest dilution of sera that prevented the production of CPE in the indicator cells. Serum from infected rabbit with VACV and fetal bovine serum were used as positive and negative controls, respectively.

Six out of eight inoculated animals shed virus in nasal secretions during an average of 5 days (days 1 to 9pi) and seroconverted to VACV (VN titers of 2 to 16 at day 30pi). Viral DNA was detected by PCR in pools of peripheral blood between days 1 and $10 \mathrm{pi}$, supporting systemic viral spread following IN inoculation. In spite of efficient virus replication and systemic spread, the animals remained healthy. No local (nasal) or systemic clinical signs (temperature, alertness, food and water consumption, weight gain) were observed. Likewise, no virus shedding was detected 
in faeces. These results showed that guinea pigs are susceptible to VACV infection but do not develop disease, under our experimental conditions.

Wild rodents have been investigated as possible reservoirs for VACV in Brazilian regions where the cattle and human cases have been reported. Positive serology and viral particles have been found in some mice species living in the affected farms (ABRAHÃO et al., 2009). The isolated virus was shown to be genetically and phenotypically similar to the virus infecting dairy cows and milkers in this outbreak, suggesting a possible epidemiological link (ABRAHÃO et al., 2009).

In the present study, VACV susceptibility and excretion by guinea pigs would be compatible with a possible participation of a related species ("preás") in the epidemiology of VACV. Even though such extrapolation would appear excessive, we sought to investigate the potential virus transmission by inoculated animals.

The transmissibility of VACV by guinea pigs was investigated in three experiments: in Exp. \#1, nine controls (non-inoculated) were housed together with two animals inoculated IN with $1 \mathrm{~mL}$ of a mixture of P1V and P2V $\left(10^{6} \mathrm{TCID}_{50} \cdot \mathrm{ml}^{-1}\right)$. In Exp. \#2, four sentinel guinea pigs were housed in a cage $5 \mathrm{~cm}$ distant from another cage housing four animals inoculated with P1V + P2V $\left(10^{6} \mathrm{TCID}_{50} \cdot \mathrm{ml}^{-1}\right)$. The only contact between the two groups would be by aerosols. In Exp. \#3, four sentinel animals received water and food contaminated with faeces containing VACV. Animals were monitored during 60 (Exp. \#1), 30 (Exp. \#2) and 45 days (Exp. \#3). VN performed after the observation period resulted negative for VACV antibodies. These results demonstrated that virus excretion by inoculated animals did not result in transmission to sentinel animals, regardless the proximity of the contact. The lack of transmission may be attributed to the low titers of virus shedding by inoculated animals (below $10^{1.8}$ $\mathrm{TCID}_{50} \cdot \mathrm{ml}^{-1}$ ).

Summarizing, the results obtained herein demonstrate that guinea pigs are susceptible to infection with VACV strains isolated from horses since they replicate, shed the virus and seroconverted. The magnitude of virus shedding, however, seemed not to suffice to ensure transmission. Although using a related species (guinea pigs) rather than the target animal species ("preás”), these results argue against the participation of "preás" in the maintenance and transmission of VACV in nature. Obviously, definitive evidence would be obtained after screening "preás" for VACV antibodies in the wild and definitively proving they are not susceptible to VACV infection.

\section{BIOETHICS AND BIOSSECURITY COMMITTEE APPROVAL}

All animal proceedings were approved by Committee for Ethics and Animal Welfare of Universidade Federal de Santa Maria (Protocol 23081.018003/2010-22; decision 97/2010)

\section{REFERENCES}

ABRAHÃO, J.S. et al. Rapid detection of orthopoxvirus by a semi-nested PCR directly from clinical specimes: a useful alternative for routine laboratories. Journal of Medical Virology, v.82, n.4, p.692-699, 2010. Available from: <http:/ /www.ncbi.nlm.nih.gov/pubmed/20166167>. Accessed: jan 31, 2012. doi: 10.1002/jmv.21617.

ABRAHÃO, J.S. et al. One more piece in the VACV ecological puzzle: could peridomestic rodents be the link between wildlife and bovine vaccinia outbreaks in Brazil? PLoS One, v.4, n.10, p.e7428, 2009. Available from: <http://www.plosone.org/ article/info:doi\%2F10.1371\%2Fjournal.pone.0007428>. Accessed: jan 31, 2012. doi: 10.1371/journal.pone.0007428.

BAXBY, D. The origins of vaccinia virus. Journal of Infectious Disease, v.136, n.3, p.453-455, 1977. Available from: <http://jid.oxfordjournals.org/content/136/3/453.long>. Accessed: jan 31, 2012. doi: 10.1093/infdis/136.3.453.

BRUM, M.C.S. et al. An outbreak of orthopoxvirus-associated disease in horses in southern Brazil. Journal of Veterinary Diagnostic Investigation, v.22, n.1, p.143-147, 2010. Available from: <http://vdi.sagepub.com/content/22/1/ 143.full>. Accessed: jan 31, 2012. doi: 10.1177/ 104063871002200132 .

BULLER, R.M.; PALUMBO, G.J. Poxvirus pathogenesis. Microbiological Reviews, v.55, n.1, p.80-122, 1991. Available from: <http://www.ncbi.nlm.nih.gov/pubmed/ 1851533>. Accessed: jan 31, 2012. doi: 0146-0749/91/010080$43 \$ 02.00 / 0$

CAMPOS, R.K. et al. Assessing the variability of Brazilian vaccinia virus isolates from a horse exanthematic lesion: coinfection with distinct viruses. Archives of Virology, v.156, n.2, p.275-283, 2011. Available from: <http:// www.springerlink.com/content/252n3x54250131p1/>. Accessed: jan 31, 2012. doi: 10.1007/s00705-010-0857-z.

CARGNELUTTI, J.F. et al. Vaccinia viruses isolated from cutaneous disease in horses are highly virulent for rabbits. Microbial Pathogenesis, v.52, n. 3, p.192-199, 2011. Avaliable from: <http://www.sciencedirect.com/science/article/ pii/S0882401011002191>. Acessed: May 7, 2012.

CARGNELUTTI, J. F. et al. Vaccinia viruses isolated from skin infection in horses produced cutaneous and systemic disease in experimentally infected rabbits. Research in Veterinary Science, 2012b. In press. <Avaliable from: http:// www.sciencedirect.com/science/article/pii/S0034528811005054>. Acessed: may 7, 2012.

da FONSECA, F.G. et al. Characterization of a vaccinia-like virus isolated in a Brazilian forest. Journal of General Virology, v.83, n.1, p.223-228, 2002. Available from: <http:/ 
/www.springerlink.com/content/252n3x54250131p1/>. Accessed: jan 31, 2012.

DAMASO, C.R. et al. An emergent poxvirus from humans and cattle in Rio de Janeiro state: Cantagalo virus may derive from Brazilian smallpox vaccine. Virology, v.277, n.2, p.439-449, 2000. Available from: <http://www.sciencedirect.com/science/ article/pii/S0042682200906032>. Accessed: jan 31, 2012. doi: http://dx.doi.org/10.1016/j.bbr.2011.03.031.

FERREIRA, J.M. et al. Virulence in murine model shows the existence of two distinct populations of Brazilian vaccinia virus strains. PLoS One, v.3, n.8, p.e3043, 2008. Available from: <http://www.ncbi.nlm.nih.gov/pmc/articles/PMC2518622/>. Accessed: jan 31, 2012. doi: 10.1371/journal.pone.

KROON, E.G. et al. Zoonotic Brazilian vaccinia virus: from field to therapy. Antiviral Research, v.92, n.2, p.150-163, 2011. Available from: <http://www.sciencedirect.com/science/
article/pii/S0166354211004190>. Accessed: jan 31, 2012. doi: dx.doi.org/10.1016/j.antiviral.2011.08.018.

PFEFFER, M.; MEYER, H. Poxvirus diagnostics. In: MERCER, A.A. et al. Poxviruses. Berlin: Birkhauser Verlag, 2007. p.355-373.

SANTOS, T.G. et al. Mamíferos do campus da Universidade Federal de Santa Maria, Rio Grande do Sul, Brasil. Biota Neutropica, v.8, n.1, 2008. Available from: <http:// www.scielo.br/pdf/bn/v8n1/a15v8n1.pdf > . Accessed: jan 31, 2012. doi: dx.doi.org/10.1590/S1676-06032008000100015.

SILVA-FERNANDES, A.T. et al. Natural human infections with vaccinia virus during bovine vaccinia outbreaks. Journal of Clinical Virology, v.44, n.4, p.308-313, 2009. Available from: <http://www.journalofclinicalvirology.com/article/S13866532(09)00037-7>. Accessed: jan 31, 2012. doi: 10.1016/ j.jcv.2009.01.007. 